\title{
Antioxidant activity of seeds and sprouts of celery crops
}

\author{
(C) Valery N. Zelenkov, ${ }^{1,2,3}$ Maria I. Ivanova, ${ }^{1}$ \\ Vyacheslav V. Latushkin, ${ }^{3}$ and Anatoly A. Lapin ${ }^{4 *+}$ \\ ${ }^{1}$ All-Russian Scientific Research Institute of Vegetable Growing Vegetables is a Branch of the Federal \\ Research Center for Vegetable Growing - the Branch of FSBSI "Federal Scientific Vegetable Center"500 \\ Vereya village.Ramenskoe district. Moscow region, Russia, 140153.E-mail: ivanova_170@mail.ru \\ ${ }^{2}$ All-Russian Scientific Research Institute of Medicinal and Aromatic Plants. \\ Greene St., 7. Moscow, 117216. Russia.E-mail: zelenkov-raen@mail.ru \\ ${ }^{3}$ ANO Development Strategies Institute, St. Red Proletarian, 16, under. 5. \\ Moscow, 125319. Russia.E-mail: slavalat@yandex.ru \\ ${ }^{4}$ Department of Water Bioreservices and Aquaculture. Kazan Energy University. Krasnoselskaya St., 51. \\ Kazan, 420066. Republic of Tatarstan. Russia. Phone: +7 (843) 519-42-67. E-mail: lapinanatol@mail.ru
}

\begin{abstract}
*Supervising author; ${ }^{+}$Corresponding author Keywords: carrots, coriander, pasternak, chicory, seeds, sprout, microgreens, antioxidant properties, seed germination, germination.
\end{abstract}

\begin{abstract}
The study examined germination of seeds, antioxidant properties of seeds, sprouts and biomass of four vegetable crops under controlled conditions under various modes of seed drying. After thermal dehydration of the seeds (drying of samples at $105^{\circ} \mathrm{C}$ ), a sharp decrease in sowing properties occurs compared to air drying. Thermal dehydration strongly affects the viability of seeds and plants, but the level of adaptation to this stress effect is genetically determined and associated with metabolic features, forms and the state of water in plant cells and tissues. So, coriander seeds completely lose germination, and chicory seeds germinate quite well. New data are obtained on seed viability, microzelenium biomass formation and change of total antioxidant activity of studied vegetable crops under conditions of increased temperatures. In addition to chicory, carrot seeds showed some resistance to thermal dehydration. The height of the sprouts in chicory in experimental and control versions is close, while in carrots they differ almost 9 times. The yield of microselenium of carrots decreased by 11.5 times with the use of seeds subjected to thermal dehydration, the yield of chicory microselenium - by 2.7 times. The antioxy-data activity of coriander seeds, carrots and pasternaci decreases after thermodehydration, chicory seeds practically do not change. The antioxidant activity of sprouts is several times higher than that of seeds, which is characteristic of all studied crops. The formation of microzelenium during dark selection lasts no more than 2 weeks from the moment of sowing, obviously, therefore, it is impractical to grow microzelenium in the dark longer than this period.
\end{abstract}

\section{References}

[1] V.N. Zelenkov, A.V. Polyakov. Features of removal of water from teeth of garlic of different grades at infrared radiation at $105^{\circ} \mathrm{C}$. Collection of scientific works on the materials of the XIII International Symposium: "New and unconventional plants and prospects for their use" -Moscow: RUDN. 2019. 184p. P.164-166. (russian)

[2] V.N. Zelenkov, M.N. Pavlov, Z.I. Usanova. Dynamics of water removal from girasol leaves and tubers of the variety Interest in infrared radiation at $105^{\circ} \mathrm{C}$. New and non-traditional plants and prospects for their use. Collection of scientific works on the materials of the XIII International Symposium: "New and unconventional plants and prospects for their use" - Moscow: RUDN. 2019. 184p. P.173-175. (russian)

[3] V.N. Zelenkov, Maria I. Ivanova, V.V. Latushkin, and A.A. Lapin. Yield and antioxidant activity of microgreens Petroselinumcrispum. Butlerov Communications. 2020. Vol.61. No.3. P.99-104. DOI: 10.37952/ROI-jbc-01/20-61-3-99

[4] V.N. Zelenkov, V.V. Latushkin, A.A. Lapin, and V.M. Kosolapov. Comparison of the sowing, harvesting and antioxidant properties of seeds and seedlings of a giant field moth (Agrostis gigantea Roth) after air drying and thermal dehydration. Butlerov Communications. 2020. Vol.61. No.3. P.120-125. DOI: 10.37952/ROI-jbc-01/20-61-3-120

[5] A.A. Lapin, V.N. Zelenkov, and M.L. Kalaida. Supplements to amaranth feed for fish cultivation. Part 3. Justification of the physical and chemical characteristics of the components of wheat and amaranth herb 

using a biochemical indicator of total antioxidant activity. Butlerov Communications. 2020. Vol.61. No.1. P.118-125. DOI: 10.37952/ROI-jbc-01/20-61-1-118

[6] V.N. Zelenkov, A.A. Lapin. МВИ-001-44538054-07. Total antioxidant activity. Method of measurement on the coolometric analyzer. VNII Vegetable Growing. Verea, Moscow Region. 2013. 19p. (russian)

[7] A.F. Bukharov, D.N. Baleev. Biology of development and germination of pasternak seeds. News of the Orenburg State Agrarian University. 2013. No.41. P.45-48. (russian)

[8] E.G. Kozar, M.I. Fedorova and others. Pasternak: reasons for the decrease in germination of seeds during storage. Sb. V Between. scientific npakm. conf., "Introduction of non-traditional and rare plants". 2004. Vol.2. P.22-23. (russian)

[9] V.A. Ludilov. Semenology of vegetable crops. Moscow: FSNU "Rosinformagrotech". 2005. 392p. (russian)

[10] N.A. Golubkina, T.V. Kiseleva, E.V. Viktorova, M.I. Fedorov, O.V. Kurbakova, V.A. Kharchenko. Fatty acid composition of celery seed oil. Gavrish. 2010. No.3. P.47-49. (russian)

[11] V.N. Zelenkov, A.A. Lapin, P.V. Krutov, T.D. Dargaeva etc. Antioxidant properties of samples of pasternak seeds. Collection of works of the II International Scientific Conference "The Role of Metabolomics in Improving Biotechnological Means of Production" (Moscow, June 6-7, 2019, FSBNU VILAR). Moscow: VILAR. 2019. 615p. P.263-266. (russian) 